IZA DP No. 4354

Does Positional Concern Matter in Poor Societies?

Evidence from a Survey Experiment in Rural

Ethiopia

Alpaslan Akay

Peter Martinsson

Haileselassie Medhin

August 2009 


\title{
Does Positional Concern Matter in Poor Societies? Evidence from a Survey Experiment in Rural Ethiopia
}

\author{
Alpaslan Akay \\ IZA and University of Gothenburg \\ Peter Martinsson \\ University of Gothenburg \\ Haileselassie Medhin \\ University of Gothenburg
}

Discussion Paper No. 4354

August 2009

IZA

P.O. Box 7240

53072 Bonn

Germany

Phone: +49-228-3894-0

Fax: +49-228-3894-180

E-mail: iza@iza.org

Any opinions expressed here are those of the author(s) and not those of IZA. Research published in this series may include views on policy, but the institute itself takes no institutional policy positions.

The Institute for the Study of Labor (IZA) in Bonn is a local and virtual international research center and a place of communication between science, politics and business. IZA is an independent nonprofit organization supported by Deutsche Post Foundation. The center is associated with the University of Bonn and offers a stimulating research environment through its international network, workshops and conferences, data service, project support, research visits and doctoral program. IZA engages in (i) original and internationally competitive research in all fields of labor economics, (ii) development of policy concepts, and (iii) dissemination of research results and concepts to the interested public.

IZA Discussion Papers often represent preliminary work and are circulated to encourage discussion. Citation of such a paper should account for its provisional character. A revised version may be available directly from the author. 
IZA Discussion Paper No. 4354

August 2009

\section{ABSTRACT}

\section{Does Positional Concern Matter in Poor Societies? Evidence from a Survey Experiment in Rural Ethiopia*}

We investigated attitudes toward positionality among rural farmers in Northern Ethiopia, using a tailored survey experiment. On average, we found positional concerns neither in income per se nor in income from aid projects among the farmers. These results support the claim that positional concerns are positively correlated with absolute level of income of a country.

JEL Classification: C90, D63

Keywords: Ethiopia, positional concern, relative income

Corresponding author:

Peter Martinsson

Department of Economics

University of Gothenburg

Box 640

40530 Gothenburg

Sweden

E-mail: peter.martinsson@economics.gu.se

\footnotetext{
* The authors gratefully acknowledge financial support from the Swedish Agency for International Development Cooperation (Sida) to the Environmental Economics Unit at University of Gothenburg.
} 


\section{Introduction}

Positional (or status) concern has been a frequently-discussed and well-documented phenomenon in developed countries (e.g., Solnick and Hemenway 1998; JohanssonStenman et al. 2002; Clark et al. 2008). Thorstein Veblen (1899/2005, p. 36) introduced this issue as a broad phenomenon across society by writing "no class of society, not even the most abjectly poor, forgoes all customary conspicuous consumption”. A result of positional concerns is that the utility derived from a good depends not only on the absolute amount of the good consumed, but also on the relative amount of the good consumed compared to the consumption of other individuals. Positional concerns have been empirically investigated using data on self-reported happiness (or "subjective wellbeing” or "life satisfaction”) from surveys, as well as from tailored survey experiments. To investigate positional concerns in the happiness framework, the average income of others (denoted as relative income in these analyses) is used as an indicator to measure positional concerns. The impact of relative income on happiness is then studied, while controlling for the subject's own absolute income. The general conclusion from this resarch shows that happiness is significantly and negatively affected by relative income (e.g., Clark and Oswald 1996; McBride 2001; Ferrer-i-Carbonell 2005; Luttmer 2005; and especially Clark et al. 2008). ${ }^{1}$ Tailored survey experiments-constructed to explicitly identify the degree to which individuals care for absolute and relative income or consumption—-have also shown that people do have positional concerns both for income as well as for consumption of specific goods, such as cars and holidays (see e.g.,

\footnotetext{
${ }^{1}$ There is a discussion regarding to whom individuals compare themselves, i.e., who belongs to their reference group. It is an important issue because it determines the calculation of the average income in the reference group, which is later used when analyzing the effect of relative income on happiness (e.g., Clark and Senik 2008; and Senik 2009).
} 
Alpizar et al. 2005; Carlsson et al. 2007a; Johansson-Stenman et al. 2002; Solnick and Hemenway 1998, 2007).

In a recent paper, Clark et al. (2008) discussed the impact of relative income on happiness within and across countries. They argued that relative income concerns increase as one moves from poorer to richer countries. But still, positional concerns may also influence people in very poor countries. In the same vein, Frey and Stutzer (2002) argued that, when absolute income is above some subsistence level, other factors, such as relative income, start to influence well-being. However, most of the research on positional concerns is based on data from Western countries that are rich in absolute terms, and research on survey experiments is predominantly based on preferences stated by well-off (comparatively) university students in Western countries. Some exceptions exist, such as the study by Carlsson et al. (2007b) in Vietnam, where they found very low positional concerns among poor rural Vietnamese farmers. ${ }^{2}$ Solnick and Hemenway (2007) found that U.S. and Chinese individuals had different degrees of positional concerns on different goods. While Chinese consider income, personal education, and vacation time as positional, individuals from the United States considered attractiveness and intelligence as positional.

The objective of this paper is to test whether positional concerns matter among extremely poor people using a two-part survey experiment. Our study was conducted in

\footnotetext{
${ }^{2}$ Using a different approach, Banerjee and Duflo (2007) investigated spending patterns in poor households in Udaipur, India. Their findings indicated that poor households spend a substantial proportion of their total consumption on festivals, tobacco, and alcohol. In another study, van Kempen (2003) found that poor people in Bolivia show positional concern by preferring goods with designer or brand labels.
} 
Northern Ethiopia, ${ }^{3}$ which is one of the poorest regions in the world, using a similar set up to Alpizar et al. (2005), for example. We surveyed farmers in the village of Abraha We Atsbaha, in northern Ethiopia. The experiment focused on positional concerns in two dimensions: 1) yearly income from all sources, and 2) income from an aid package. In the first experiment, we tested for positional concerns for overall income and, more specifically, for the claim in Clark et al. (2008) that the positional concerns should be lower in a very poor country — which to our knowledge is an untested empirical question. The second experiment tests whether there are positional concerns for income from an aid package. This is a potential important issue for the well-being of those people who are not selected to receive the aid package and, thus, for the overall welfare effect of the aid project. Aid-based development projects often select a smaller fraction of households in a village to be "model farmers" for a new farm technology or improved input, while in other cases aid projects may target certain household in a community, according to some criteria, such as income and family size. If people do have positional concerns, then how the aid project is implemented may have significant implications to overall welfare in the community. The remaining part of the paper is organized as follows. Section 2 gives the design of the experiment and the method behind it. Section 3 presents the results of the experiments, and the last section concludes the paper.

\footnotetext{
${ }^{3}$ In 2002, Ethiopia's purchasing power parity per capita was $2.05 \%$ of that of the United States. Ethiopia ranked the seventh poorest country in the world and one of the top recipients of foreign aid (World Bank 2004).
} 


\section{Experiment Design}

The two most common ways to model relative position in a utility framework are 1) a ratio comparison utility function, $U=v(x, x / \bar{x})$, where $x$ is the individual's income and $\bar{x}$ is the average income in the society (e.g., Boskin and Sheshinski 1978; Layard 1980; Persson 1995); or 2) an additive comparison utility function, $U=v(x, x-\bar{x})$ (e.g., Akerlof 1997; Knell 1999; Ljungqvist and Uhlig, 2000). In this paper, we chose to apply the following additive comparison utility function

$$
v=(1-\gamma) x+\gamma(x-\bar{x}),
$$

where $\gamma$ measures the marginal degree of positional concern, i.e., it measures the proportion of the total change in utility that comes from an increase in relative income after a marginal increase of own income.

In order to test the effect of positional concern in both the dimensions of income per se and income from aid package, we applied a survey experiment. We created a scenario describing the situation where individuals are about to make decision. In the experiment on income, subjects were told that they could choose between living in two villages, and that the annual income (from all sources) earned by them and other people differed in each village. The income was described as the annual income in Ethiopian birr (ETB). ${ }^{4}$ The respondents were asked to make six choices between paired alternatives that would prefer to have implemented. Because most of our subjects had no formal education and many were illiterate, the instructions were given verbally in the local language (Tigrinya), and the same procedure was applied for the socioeconomic questions.

\footnotetext{
${ }^{4}$ The official exchange rate was US\$ $1=$ ETB 9.67 at the time of the survey.
} 
The income across the choice sets was constructed to measure the degree of positional concern. For example, in the first choice situation, an individual's yearly income in alternative A was ETB 2,990 and the average yearly income for others in the village was ETB 3,900; while, in alternative B, the individual's yearly income was ETB 2,860 and the average yearly income in the village was also lower at ETB 2,600. (See box 1 in the appendix for the full description of the scenario read to the subjects.)

If a respondent was indifferent between living in these two villages, then we have, in the case of the additive comparison utility function, that

$$
x_{A}-\bar{x}_{A}=x_{B}-\bar{\gamma}_{B} .
$$

The marginal degree of positional concern for the first choice set can be calculated as

$$
\gamma=\frac{x_{A}-x_{B}}{\bar{x}_{A}-\bar{x}_{B}}=\frac{2990-2860}{3900-2600}=0.1
$$

Thus, the marginal degree of positional concern $\gamma$ is equal to 0.1 in this case. If the respondent chose to live in village $\mathrm{A}$, then $\gamma<0.1$, or (otherwise) at least equal to 0.1 . The subjects were asked to make repeated choices between two villages to live in, which gave us information about their degree of positional concerns, at least within an upper and lower bound. The construction of our survey was such that alternative A remained the same throughout the experiments, while the levels varied for alternative B. The levels used in the experiments, together with the implicit marginal degree of positional concern, are summarized in table $1 .^{5}$

\footnotetext{
${ }^{5}$ The levels applied in the survey experiment were affected by the results from two smaller pilot tests. The implicit marginal degree of positional concern with the ratio comparison utility function took the
} 
(Table 1 about here)

We determined the implicit marginal degree of positional concerns for a specific individual as follows. When an individual preferred alternative $\mathrm{A}$ over alternative $\mathrm{B}_{i}(i=$ $1,2,3,4,5,6)$, then we knew that the marginal degree of positional concern was below the level calculated at that specific choice situation. In the survey, the respondents were asked to make choices until alternative A was chosen, meaning that each respondent was presented with a maximum of six choices for income.

The income experiment from aid project was constructed in the same way, where subjects were told that they could choose between living in two villages, where their income from implemented bee-keeping packages, as well as the other people's, would differ in each village. The income from bee keeping in a village was described as the annual income for them and the mean annual income for the others in the village. This was then followed by six paired choices to trace the marginal degree of positionality. (The full description of scenario read to the subjects is in box 2 in the appendix.)

\section{Results}

Table 2 shows the frequency distribution of the marginal degree of positional concerns for the two survey experiments among 94 farmers. ${ }^{6}$ Most of the subjects were not

values of $0.110,0.224,0.345,0.471,0.605$, and $0.746\left(x_{A} / \bar{x}_{A}^{\gamma}=x_{B} / \bar{x}_{B}^{\gamma}\right)$, and marginal degree of positional concern was calculated with $\gamma=\ln \left(x_{A} / x_{B}\right) / \ln \left(\bar{x}_{A}^{\gamma} / \bar{x}_{B}^{\gamma}\right)$.

${ }^{6}$ The subjects were randomly selected from a total of 584 households. 
concerned with their positionality and chose alternative $\mathrm{A}$ in the first choice situation (60.6 and 65.7 percent for income per se and income from aid packages, respectively). The estimated median degree of positionality was 0 for both experiments, and the mean degree of positionality was 0.158 for income per se and 0.177 for the income obtained from the aid projects. These results obtained from raw data support the hypothesis that the concern for relative position in poor societies is a very small component of individuals' total utility. ${ }^{7}$

(Table 2 about here)

We also analyzed the degree of positional concerns in the two experiments using regression analyses. Table 3 reports interval regressions for the two experiments, where the marginal degree of positionality is explained by socioeconomic characteristics of the subjects. $^{8}$ Income and land size had no significant influence on preferences for positional concerns. The only significant demographic variables were marital status and gender. Female subjects were significantly less positional than male subjects in both experiments. Married subjects were more concerned with their position with income from aid packages. Members of religious groups seemed partially more concerned about their relative position for total yearly income. On the other hand, frequent church goers did not seem to have positional concerns. ${ }^{9}$

\footnotetext{
${ }^{7}$ The results given in tables 2 and 3 are robust to specification of the utility function, which is mainly due to the fact that most individuals switched in their first-choice situation.

${ }^{8}$ In the interval regression, we set the lower and upper bounds, as shown in table 1 . In case of extreme choices, i.e., where A is chosen in first choice set or is never chosen, we made the lower bound 0 in the former case and the upper bound 1 in the latter case.

${ }^{9}$ The village, which was named after its centruies-old rock-hewn churches, is almost entirely Orthodox Christian.
} 
(Table 3 about here)

The regression results presented above can also be used to estimate the mean degree of positional concerns conditional on socioeconomic characteristics of the subjects. To show this, we first predicted the marginal degree of positionality for each individual, and then calculated the mean degree of positional concern for the entire sample. Using the bootstrap technique, the mean level of predicted marginal degree of positional concerns was 0.268 for the income per se, with a 95 percent confidence interval of (0.123, 0.412) using 1000 replications. The mean level of predicted marginal degree of positional concerns for income from the aid package was 0.188 and 95 percent confidence interval is $(0.06,0.314)$. The hypothesis that mean marginal degree of positional concerns equals zero can be rejected for both goods ( $\mathrm{p}$-value $=0.000$ and $\mathrm{p}$ value $=0.004$, respectively) .

Our results indicate a very low degree of positional concerns in comparison with other studies, which used similar tools to estimate the mean degree of positional concerns in richer countries in the world. For instance, Carlsson et al. (2007a) estimated a mean degree of positional concern for income in the range of 0.59 and 0.71 , using a random sample of Swedish population, while Alpizar et al. (2005) estimated the degree to be 0.45, using a sample of Costa Rican university students. The study that we consider closest to our study and our findings is Carlsson et al. (2007b), which used poor Vietnaesse farmers and found a median degree of positionality of 0.25 (mean degree of positionality is 0.28 ). Overall, our results are consistent with the idea discussed by Clark et al. (2008) that individuals in poorer countries are less positionally concerned. 


\section{Discussions and Conclusion}

This paper investigates the hypotheses concerning whether extremely poor individuals have positional concerns in the dimensions of income per se and income from an aid package. We used a survey experiment approach, in which the individuals chose between two villages to live in where they and the other people had different average incomes in each village, to calculate the marginal degree of positional concerns in a rural part of Ethiopia. We found the estimated mean degree of positional concerns to be very low in absolute terms. Our results showed much lower concern for positionality compared to similar studies conducted in developed countries. Moreover, our results are in line with the discussion in Clark et al. (2008) that people in poorer countries have lower positional concerns.

There are several explanations for why the low degree of positional concern occurred. Our subject pool is extremely poor and during some part of the year they need foreign aid for daily food. This supports Frey and Stutzer's (2002) argument that people are concerned with positionality above a certain threshold. Moreover, the role of kinship relations is higher in rural communities in Ethiopia, compared to urban areas in Western countries, as well as informal networks (such as a labor exchange network like Debo) and insurance mechanisms (such as rotating savings and credit associations like Iquib) exist. As a result, individuals may attach a higher value to the overall welfare of their community. Clearly, more work is necessary to understand how these factors affect attitudes towards positionality and to learn in which cases our results hold. Overall, our 
results imply that the income of others and from aid projects only marginally affect the utility of other individuals who live in the same village or participate in the same aid projects, which is important information for development policy. 


\section{References}

Akerlof, G.A. 1997. Social Distance and Social Decisions. Econometrica 65: 1005-1027

Alpizar, F., F. Carlsson, and O. Johansson-Stenman. 2005. How Much Do We Care about Absolute versus Relative Income and Consumption? Journal of Economic Behavior and Organization 56: 405-421.

Banerjee, A.V., and E. Duflo. 2007. The Economic Lives of the Poor. Journal of Economic Perspectives 21: 141-167.

Boskin, M.J., and E. Sheshinski. 1978. Individual Welfare Depends upon Relative Income. Quarterly Journal of Economics 92: 589-601.

Carlsson, F., O. Johansson-Stenman, and P. Martinsson. 2007a. Do You Enjoy Having More than Others? Survey Evidence of Positional Goods. Economica 74: 586-598.

Carlsson, F., P.K. Nam, M. Linde-Rahr, and P. Martinsson. 2007b. Are Vietnamese Farmers Concerned with Their Relative Position in Society? Journal of Development Studies 43: 1177-1188.

Clark, A.E., and A.J. Oswald. 1996. Satisfaction and Comparision Income. Journal of Public Economics 61: 359-381.

Clark, A.E., P. Frijters, and M.A. Shields. 2008. Relative Income, Happiness, and Utility: An Explanation for the Easterlin Paradox and Other Puzzles. Journal of Economic Literature 46(1): 96-144.

Clark, A.E., and C. Selnik. 2008. Who Compares to Whom? The Anatomy of Income Comparisons in Europe. PSE Working Paper 2008-65. Paris: PSE (École normale supérieure).

Ferrer-i-Carbonell A., 2005. Income and Well-Being: An Empirical Analysis of the Comparison Income Effect. Journal of Public Economics 89: 997-1019.

Frey, B.S., and A. Stutzer. 2002. What Can Economists Learn from Happiness Research? Journal of Economic Literature 40: 402-435.

Johansson-Stenman, O., F. Carlsson, and D. Daruvala. 2002. Measuring Future Grandparents' Preferences for Equality and Relative Standing. Economic Journal 112: 362-383.

Knell, M. 1999. Social Comparisons, Inequality, and Growth. Journal of Institutional and Theoretical Economics 155: 664-695.

Layard, R. 1980. Human Satisfaction and Public Policy. Economic Journal 90: 737-750.

Ljungqvist, L., and H. Uhlig. 2000. Tax Policy and Aggregate Demand Management under Catching Up with the Joneses. American Economic Review 90: 356-366.

Luttmer, E.F.P. 2005. Neighbors as Negatives: Relative Earnings and Well-Being. The Quarterly Journal of Economics 120: 963-1020.

McBride, M. 2001. Relative-Income Effects on Subjective Well-Being in the CrossSection. Journal of Economic Behavior and Organization 45: 251-278. 
Persson, M. 1995. Why Are Taxes So High in Egalitarian Societies? Scandinavian Journal of Economics 97: 469-476.

Senik, C. 2009, forthcoming. Direct Evidence on Income Comparisons and Their Welfare Effects. Journal of Economic Behavior and Organization.

Solnick, S., and D. Hemenway. 1998. Is More Always Better? A Survey on Positional Concerns. Journal of Economic Behavior \& Organization 37: 373-383.

Solnick, S., and D. Hemenway. 2007. Positional Goods in the United States and China. Journal of Socio-Economics 36: 537-545.

van Kempen, L. 2003. Are the Poor Willing to Pay a Premium for Designer Labels? A Field Experiment in Bolivia. Oxford Development Studies 32: 205-24.

Veblen, T. 1899/2005. The Theory of the Leisure Class. Digireads.com.

World Bank. 2004. World Development Report 2004: Making Services Work for the Poor. Washington, DC: World Bank. 
Table 1 Alternatives in Experiment

\begin{tabular}{cccccc}
\hline \hline & \multicolumn{2}{c}{$\begin{array}{c}\text { Individual's annual } \\
\text { income }\end{array}$} & \multicolumn{2}{c}{$\begin{array}{c}\text { Average annual } \\
\text { income in village }\end{array}$} & $\begin{array}{c}\text { Implicit marginal } \\
\text { degree of positionality }\end{array}$ \\
\cline { 2 - 6 } & $\begin{array}{c}\text { Income } \\
\text { (ETB) }\end{array}$ & $\begin{array}{c}\text { From aid } \\
\text { (ETB) }\end{array}$ & $\begin{array}{c}\text { Income } \\
\text { (ETB) }\end{array}$ & $\begin{array}{c}\text { From aid } \\
\text { (ETB) }\end{array}$ & \\
\hline Alternative $\mathrm{A}$ & 3,900 & 900 & 2,990 & 690 & 0.1 \\
Alternative $\mathrm{B}_{1}$ & 2,600 & 600 & 2,860 & 660 & 0.2 \\
Alternative $\mathrm{B}_{2}$ & 2,600 & 600 & 2,730 & 630 & 0.3 \\
Alternative $\mathrm{B}_{3}$ & 2,600 & 600 & 2,600 & 600 & 0.4 \\
Alternative $\mathrm{B}_{4}$ & 2,600 & 600 & 2,470 & 570 & 0.5 \\
Alternative $\mathrm{B}_{5}$ & 2,600 & 600 & 2,340 & 540 & 0.6 \\
Alternative $\mathrm{B}_{6}$ & 2,600 & 600 & 2,210 & 510 & \\
\hline
\end{tabular}


Table 2 Results of the Experiments

\begin{tabular}{ccccccc}
\hline \hline & \multicolumn{3}{c}{ Total income } & \multicolumn{3}{c}{ Income from aid projects } \\
\cline { 2 - 7 } $\begin{array}{c}\text { Marginal degree of } \\
\text { positionality }\end{array}$ & No. & Freq. & $\begin{array}{l}\text { Cum. } \\
\text { Freq. }\end{array}$ & No. & Freq. & Cum. Freq. \\
\hline$\gamma<0.1$ & 62 & 65.66 & 65.66 & 57 & 60.64 & 60.64 \\
$0.1<\gamma<0.2$ & 6 & 6.38 & 72.34 & 4 & 4.26 & 64.89 \\
$0.2<\gamma<0.3$ & 3 & 3.19 & 75.53 & 4 & 4.26 & 69.15 \\
$0.3<\gamma<0.4$ & 16 & 17.02 & 92.55 & 17 & 18.09 & 87.23 \\
$0.4<\gamma<0.5$ & 2 & 2.13 & 94.68 & 9 & 9.57 & 96.81 \\
$0.5<\gamma<0.6$ & 2 & 2.13 & 96.81 & 2 & 1.06 & 97.87 \\
$\gamma \geq 0.6$ & 3 & 3.19 & 100.0 & 1 & 2.13 & 100.0 \\
\hline
\end{tabular}


Table 3 Interval Regression Estimates of the Degree of Positionality

\begin{tabular}{|c|c|c|c|c|c|}
\hline & \multicolumn{2}{|c|}{ Total income } & \multicolumn{2}{|c|}{$\begin{array}{c}\text { Income from aid } \\
\text { projects }\end{array}$} & \multirow[t]{2}{*}{ Mean } \\
\hline & Coefficient & p-value & Coefficient & p-value & \\
\hline Age /100 & 0.437 & 0.539 & 0.923 & 0.229 & 0.430 \\
\hline Age-squared $/ 10,000$ & -0.595 & 0.416 & -0.896 & 0.236 & 0.206 \\
\hline Marital-status (married = 1) & 0.053 & 0.113 & 0.066 & 0.086 & 0.787 \\
\hline Gender $($ female $=1)$ & -0.080 & 0.049 & -0.087 & 0.022 & 0.510 \\
\hline Health-status (healthy = 1) & -0.002 & 0.964 & 0.034 & 0.322 & 0.712 \\
\hline Number of adults in home & -0.007 & 0.659 & 0.006 & 0.701 & 2.691 \\
\hline Education (at least one year $=1$ ) & -0.053 & 0.144 & 0.007 & 0.870 & 0.521 \\
\hline Log (land size) & -0.025 & 0.493 & -0.010 & 0.819 & 0.546 \\
\hline Log (per capita income) & -0.033 & 0.196 & -0.022 & 0.454 & 4.462 \\
\hline $\begin{array}{l}\text { Membership-farmer association } \\
(\text { member = 1) }\end{array}$ & -0.026 & 0.570 & -0.041 & 0.336 & 0.287 \\
\hline $\begin{array}{l}\text { Membership-religious group (member } \\
=1 \text { ) }\end{array}$ & 0.065 & 0.093 & 0.035 & 0.232 & 0.617 \\
\hline $\begin{array}{l}\text { Frequency of church attendance } \\
\text { (weekly) }\end{array}$ & -0.007 & 0.494 & -0.021 & 0.045 & 3.241 \\
\hline Constant & 0.287 & 0.225 & 0.071 & 0.786 & \\
\hline Ln(Sigma) & -1.883 & 0.000 & -1.879 & 0.000 & \\
\hline Number of observations & 91 & & 91 & & \\
\hline
\end{tabular}

Notes: Health status is obtained from a question with this range of answers: 1 = very good; $2=$ good; 3 = neither good nor poor; $4=$ poor; and $5=$ very poor. The variable used here is a dummy: health status $=1$, if subject answer is 1,2 or 3 .

Per capita income is calculated by dividing the income to household size.

Education is a dummy variable and it is equal to unity if the subject is educated at least one year. Land size is measures in hectares. 


\section{Appendix}

\section{Box 1: Instructions for Income Experiment}

Imagine that you can choose to live one of two villages. Your yearly income and the average yearly income of the others in the villages differs between the two villages.

I will tell you the amount of income for you and the average income for others in each village. I will ask you to choose which village you would like to live in. Let me illustrate this choice by the following example.

Village A:

- Your yearly income is 2,530 Birr

- The yearly average village income is 3,300 Birr

Village B:

- Your yearly income is 2,310 Birr

- The yearly average village income is 2,200 Birr

In this example, your yearly income is 220 Birr more in Village A than in Village B. In Village A, you earn 770 Bir less than average income in the village, while in Village B you get 110 Birr more. Given this difference, you can either choose to live in Village A or B. (Repeat question and example)

Now, I’ll ask you to make your choice between different villages.

(Using the table below, ask the first question in the following way)

In Village A, your yearly income is 2,990 Birr, while the average yearly income in the village is 3,900 Birr. In Village $B_{1}$, your yearly income is 2,860 Birr, while the average yearly income in the village is 2,600 Birr. In which village, $\mathrm{A}$ or $\mathrm{B}_{1}$, do you want to live?

(If the respondent chooses $A$, stop. If respondent chooses $B_{1}$, ask her/him to choose between $A$ and $B_{2}$. Do not change the format of the question except for the numbers. Follow the same procedure for the other choices.)

\begin{tabular}{|c|c|c||}
\hline Alternatives & Your yearly income (Birr) & $\begin{array}{c}\text { Yearly average income in the } \\
\text { village (Birr) }\end{array}$ \\
\hline$A$ & 2,990 & 3,900 \\
\hline$B_{1}$ & 2,860 & 2,600 \\
\hline$A$ & 2,990 & 3,900 \\
\hline$B_{2}$ & 2,730 & 2,600 \\
\hline$A$ & & 3,900 \\
\hline$B_{3}$ & 2,990 & 2,600 \\
\hline$A$ & 2,600 & 3,900 \\
\hline$B_{4}$ & 2,990 & 2,600 \\
\hline$A$ & 2,470 & 3,900 \\
\hline$B_{5}$ & & 2,600 \\
\hline$A$ & 2,990 & 3,900 \\
\hline$B_{6}$ & 2,340 & 2,600 \\
\hline
\end{tabular}




\section{Box 2: Instructions for Aid Package Experiment}

Assume that you are introduced to two different bee-keeping aid packages which will make you earn money. These packages are distributed for free by the government. You can choose one of the packages you want for your village and there will be no cost to you or to the village.

Your income and the income of other people in your village changes with the package you prefer from the two alternatives.

I will tell you the amount of income for you and for others in the village in each alternative, and then I will ask you to choose one of the two. Let me illustrate this choice by the following example.

\section{Alternative A:}

- Your yearly income from the package is 575 Birr

- The yearly average village income from the package is 750 Birr Alternative B:

- Your yearly income from the package is 550 Birr

- The yearly average village income from the package is 500 Birr

In this example, you get the 25 Birr more in Alternative A than in Alternative B. In alternative A, you get 175 less than average income in the village, while in Alternative B you get 50 Birr more. Given this difference, you can either choose A or B for your village. (Repeat question and example)

Now, I’ll ask you to make your choice between different alternatives.

(Using the table below, ask the first question in the following way)

In package A, your yearly income is 690 Birr, while the average yearly income in your village is 900 Birr. In package $B_{1}$, your yearly income is 660 Birr, Birr while the average yearly income in your village is 600 Birr. Which alternative package, $\mathrm{A}$ or $\mathrm{B}_{1}$, do you want for you village?

(If the respondent chooses $A$, stop. If respondent chooses $B_{1}$, ask her/him to choose between $A$ and $B_{2}$. Do not change the format of the question except for the numbers. Follow the same procedure for the other choices.)

\begin{tabular}{|c|c|c||}
\hline Alternatives & $\begin{array}{c}\text { Your yearly income from the } \\
\text { package (Birr) }\end{array}$ & $\begin{array}{c}\text { Yearly average income for your } \\
\text { village from the package (Birr) }\end{array}$ \\
\hline$A$ & 690 & 900 \\
\hline$B_{1}$ & 660 & 600 \\
\hline$A$ & 690 & 900 \\
\hline$B_{2}$ & 630 & 600 \\
\hline$A$ & & 900 \\
\hline$B_{3}$ & 690 & 600 \\
\hline$A$ & 600 & 900 \\
\hline$B_{4}$ & & 600 \\
\hline$A$ & 690 & \\
\hline$B_{5}$ & 570 & 900 \\
\hline$A$ & & 600 \\
\hline$B 6$ & 690 & 900 \\
\hline & 540 & 600 \\
\hline
\end{tabular}

